\title{
Vulnerabilities of Feminist Engagement and the Challenge of Developmentalism in the South: What Alternatives?
}

\author{
Josephine Ahikire
}

\begin{abstract}
1 Introduction
In the 1980s Marjorie Mbilinyi observed that women's studies was simply catching up with the policy-oriented applied research (POAR) trends and reliance on external funding characteristic of social science in general in neocolonial Africa (1984: 291). In this observation, Mbilinyi sought to highlight the fact that the general roll-out of women's studies at the time did not promise enough in the direction of rigorous questioning, with many efforts locked up in integrationist as opposed to transformatory perspectives (Ahikire 1994; Mama 1996).
\end{abstract}

This view could be seen as representing the early alarm bells against developmentalism generally, and within the arena of feminist knowledge construction in particular. Now we are talking about reclaiming feminism. In other words, feminism - as a struggle for transformation of gender relations - has been largely conscripted into and almost swallowed up by the neoliberal discourse, with real and potentially dire consequences.

In this short reflection, I would like to turn the question the other way around in terms of the major adjustments that the feminist struggle has forced into the development discourse. The point of departure is that the feminist struggle has surely made strides both in the arena of knowledge production as well as political praxis. Perhaps, much more than many other social struggles, feminist engagement has been able to lodge a claim within the global development discourse. One could argue for instance, that in the current period, bureaucrats and development actors merely pay lip service to the whole gender equality struggle - more often than not, with a sentence on gender and women appearing here and there in policy documents and speeches. Lip service in many of the countries in Africa for example comes in the form of governments signing up to international instruments on women's rights and putting in place national gender policies that pledge commitment to gender equality, but with very little in terms of concrete operationalisation in state policy and commitment of resources (Kwesiga 2003; Ahikire 2005). But if we may pose a very basic question, why pay 'lip service'? What is the impetus to pay lip service as opposed to say, complete silence on gender relations or even negation of women? This I see as a major success of and/or for feminism. This success has been in terms of commanding a presence of the gender equality question in the development discourse and in processes of legitimisation generally.

The question at stake therefore seems to be that the outcome of this key success is and continues to be a double-edged sword, whose disintegrative effects are much fiercer and much more anchored in terms of power regimes. The feminist struggle in its challenge of patriarchal systems promises one of the most far-reaching changes given the embedded nature of gender relations. The feminist critique succeeded in breaking some of the heavily guarded boundaries. Yet feminism had critical and inherent vulnerabilities. As opposed to, say general democratisation struggles, feminism touches the core of the person and the personal. And if we are 
to recall Simone de Beauvoir (1949), for example, the bond that unites women to their oppressors is not comparable with any other.

By trying to have a command into the development arena, feminism had to reshape itself - even at the basic level of being understood. The efforts to make the gender question understood to bureaucrats and development actors at the international and national levels simultaneously engendered a different uptake on the complexity of gender relations. This is what I look at as the source of vulnerability, more or less, as success gone wrong.

\section{Feminism and 'gender and development'}

'Why would feminists invest their dreams with bureaucrats?'

This is a question that Andrea Cornwall posed in one of the discussions during a conference on gender training. ${ }^{1}$ The major concern here was that the effort to make gender understandable through gender training had in a sense backfired with paltry benefits accompanied by far-reaching losses for feminism. Here gender training was noted as the main culprit behind the depoliticisation of gender mainstreaming efforts, for example. ${ }^{2}$ Yet we could also argue that gender training is merely a reflection of the broader successes/vulnerabilities in the feminist engagement in the 1980s and 1990s. I have argued elsewhere that more and more people have been exposed to basic concepts of gender and there is comparatively more widespread basic knowledge today than 20 years ago (Ahikire 2007). Partly due to the proliferation of gender training, there is more talk and more contestation around gender identity. In my view, this visibility of gender-related concepts has had the effect of placing patriarchal norms and values under relative stress. Relative stress in a sense that the patriarchal order is compelled to move from the realm of 'orthodoxy' to that of 'heterodoxy' (Agarwal 1997), as larger numbers of people are likely to bump into the question of gender equality, whether willingly or unwillingly.

Hence, I see this whole vulnerability embedded within the operationalisation of the Gender and Development (GAD) perspective. GAD evolved within a context of robust feminist debate and promised to provide more impetus to the radical, liberal and Marxist feminist insights. This strength is drawn from the critical engagement with gender relations as social and power relations, going down to addressing complexities in the bid to transform those relations. Since development stands out as a major challenge to the South generally and to Africa in particular, GAD as an approach quickly gained popularity since it holds the potential for translating feminist engagement and/or imperatives into real change in the lived reality of women especially. For example, widespread poverty, deprivation, war and displacement, global marginalisation all make Africa a continent struggling with the problem of development. GAD in this sense, offered a handle for feminism to simultaneously speak to the problem of development as well as to its gendered nature.

However, the need to translate this into actions that make a difference in women's lives took a new turn as the feminist fraternity made efforts to make the goals and the concepts understood by - nearly everyone. And consequently, the knowledge base for and of gender and development has been viciously watered down.

GAD had progressively assumed a life of its own, and ultimately became emptied of its basic feminist imperatives. In what seems to be a direction to more pressing issues of material deprivation and abuse of human rights, GAD then evolved as a realm of 'problems' largely constructed as a field with no competing discourses. The watered down version of the concept of gender has progressively made it possible for it to be used and/or abused, comfortably even in anti-feminist circles. I use the case of Uganda to illustrate some of these issues.

\section{A reflection on Uganda's experience}

'I am a gender expert but I am not a feminist'

'I am a gender activist but I do not like feminism'

'Feminism is a luxury for the west and not for African women'

'We need a gender consultant who is practical and not abstract'

The above are very common statements one is very likely to encounter in several spaces in Uganda. A number of graduate students will define gender as referring to both men and women. GAD will be defined as the participation of both men and women in development. This conceptual slippage is often accompanied by an apologetic stance that goes like 'empowering women does not mean excluding men'. Hence, as several scholars have argued, the 
concept of gender has been taken on in a way that is emptied of its political impetus - in a way, completely divorced from feminism. How do we understand the apparent divorce between the terms gender and feminism? Whereas the question can be addressed through looking at how feminism has been appropriated, for example by donors, I would like to limit this analysis to the internal vulnerabilities within feminist engagement.

The broad motive to highlight the plight of women, the fact that women tend to be the worst victims of poverty, wars and disease (such as the HIV/AIDS pandemic) unfortunately translates into a field of 'lamentations' that may in the end carry a critical anti-feminist message. ${ }^{3}$ If we may take the example of HIV/AIDS, the relationships between the AIDS pandemic, severe poverty and gender inequalities is clear. However, the discourse on women's vulnerabilities has taken the public health route as opposed to social transformation. The notion of the female face of HIV/AIDS has over time carried within it different constructions of the female subject. While some of the interpretations stem from grounded social and biomedical analysis, others - and often the most dominant - are based on construction of the female as the problem, invariably making HIV/AIDS a female disease.

Developmentalism has also succeeded in severing the link between the personal and the political. Here we can use the example of silences around issues of sexuality. As Pereira argues, the centrality of sexuality as an integral part of the experience of being human (Pereira 2004) cannot be overemphasised. These silences illustrate how the structure of women and gender studies may be understood - within the limitations of extreme conditions matters of sexuality are seen to be a luxury in the face of 'more pressing concerns'. In Uganda, scholars like Tamale who have taken on the issue of sexuality in academia and social debate are seen as agents of Western decadence, as the majority of 'gender experts' remain in their comfort zones.

Further on in developmentalism, we have the challenge of infantilising discourses. From around the mid-1980s, the language of the marginalised/vulnerable groups has taken root. The need to highlight the different problems women face has then translated into a discourse on women - defined as intrinsically vulnerable - together with children, people with disabilities and youth. To lump women with youth and children, for example, is to give them the status as minors. The difference, though, is that the male youth will become elders - citizens. Women, by being defined specifically as 'other', as 'minor', have that status forever. In consideration of what is happening now with decentralisation processes under way, the language of marginalisation in policy documents tends to constrain women's leverage and claims. They largely become clients of local governments as opposed to actors and shapers.

One clear development stemming from the postBeijing inclination to reporting mechanisms and the whole emphasis on gender mainstreaming is the increased bureaucratisation and professionalisation of the gender equality crusade. And I see this as a direct result of the truncated success of the GAD perspective. Beijing ushered in a demand for 'gender experts', 'gender consultants' and 'gender specialists'. In Uganda, even the would-be feminist scholars and activists increasingly came to prefer the label of 'expert'.

Admittedly, there is a wealth of documentation as a result of this professionalisation. There is more information on the status of women than there ever was. However, this development has in a sense retarded the thinking around gender equality. There is a preoccupation with technical assessment and 'doing', for instance with gender audits, gender budgeting, monitoring and evaluation, information systems, and much less creative imagination.

Specifically on gender mainstreaming as a term invogue, it has engendered a bureaucratic discourse in which state functionaries can hide without necessarily being accountable to women. In Uganda, gender mainstreaming has been translated to mean that gender is a 'cross cutting' issue. What this has meant in reality is that gender remains at the rhetoric level, hanging on that one sentence usually appended onto policy statements. Gender budgeting for example would otherwise bring to the fore the whole philosophy of democratisation, redistribution and transformatory practice. Instead, it is treated in a technically static manner, devoid of political engagement and hence with very limited outcomes.

More often than not, the limited outcomes have been blamed on the 'lack of political will'. An underfunded ministry, resistance to key legislation such as the Domestic Relations Bill, ghettoisation of women in 
electoral processes, persistence of marginalisation of women in the economy - all is blamed on lack of political will. This understanding evidently oversimplifies the issue at hand. As Goetz argues:

The lack of political will explanation is too vague to be of much use, it does not direct attention to the real problems of generating political support for socially unpopular policies... In addition the lack of political will explanation ignores the problem of deep institutionalisation of gender differences and male privilege in the public sphere (Goetz 2003: 70).

The point Goetz (2003) clearly articulates is that the language employed in the contemporary period is highly depoliticised. And as Lazreg put it, there is an urgent need for feminism (particularly in the South) to re-invent its impetus (2004). The vagueness in the naming of issues at stake clearly stems from the detheorisation that has increasingly characterised the field of gender.

Can states commit themselves to full gender equality? Beijing seems to have ushered in an era of unprecedented hope in state feminism. The significance of focusing on the commitment and performance of governments as state mechanisms was articulated strongly at the 1995 Fourth World Conference on Women, in Beijing. There are basically two important points about the role of government in society in general and for gender equality in particular. One is the optimistic one, which is that governments have broader legitimacy and other critical resources to support change in society. The state in general has the command to generate political power, to effect change that would otherwise be extremely difficult to realise, especially when it comes to gender relations. The second, on the negative side, is that government actions especially in relation to transformation of gender relations may be symbolic or even cosmetic with the not so rare effect of 'damping the fires of reform' (Stetson and Mazur 1995).

The post Beijing situation seems to reflect a mixed bag. Fundamentally however, states seem to be restricted to a minimalist agenda as far as women are concerned. And this is so because states more often than not will go with initiatives that do not undermine deep-seated male privilege (Ahikire 2007). The articulation of what must be done and the how of gender fair outcomes must come from below and this necessitates a re-invigoration of the women's movement.

A current evaluation of the women's movement in Uganda is that the focus on 'doing' has resulted in an ad hoc treatment of issues. There is a lack of a longterm thread to pull issues together. A report on the women's movement in Uganda by ActionAid highlighted the frustration by a number of women actors who indicated that 'we have activists without activism, 'adhocacy', as opposed to advocacy' (ActionAid Uganda 2006). 'Adhocacy', has meant that there is inability for follow-up.

Specifically, the important question in activism has been the lack of strategies to deal with resistance. It is obvious that beneficiaries of the status quo cannot be expected to easily and willingly embrace agendas that are bound to clip their power. Yet, the women's movement pursues issues as if there is supposed to be successes only, no plan for resistance, and much less for failure (ActionAid Uganda 2006).

The focus on addressing women's problems through the state and international donors has had another subtle down side. The apparent embrace of the gender language has tended to blur the line between gains struggled for by women and handouts by government and donors. This further works to weaken the women's movement. At the risk of generalisation, we can say that the women's movement has emptied itself of agency. In Uganda, there is now a sense of loss and that women have merely handed over their gains to government.

\section{Concluding remarks}

Feminism in the South faces a critical challenge: that of addressing the problem of development without necessarily falling into the trap of developmentalism. The critical question is how to bring the politics back in both at the level of knowledge construction as well as political practice. Bringing politics back in is evidently easier said than done, especially considering the current context in which social forces have been demobilised both at national and international levels. Yet no situation should be allowed to have no alternatives.

I have argued earlier that the dominant picture of the GAD perspective is a field with no competing 
discourses. Everybody seems to agree with everybody else - a conspicuous agreement between state actors, academics, donors and civil society. At the level of knowledge creation, the very starting point is to re-invigorate gender studies and feminist theorisation. There is need for more debate and problematisation of gender relations. This more or less requires a rebirth of language, for instance to reverse the tendency of reducing fundamental concepts into buzzwords. For example, to avoid the situation where the concept of gender can be appended to practically anything, there can be a conscious effort to re-popularise the use of the concept of gender relations. Terms, such as engendering, gender mainstreaming, empowerment, gender-sensitive all have to be re-problematised.

There is need for new research on the status of the women's movement in a broad sense. Here I am thinking of a more or less action research that establishes the understanding and aspirations of women - young and old, wealthy/poor and so on.

There is also the challenge of managing success. Reflecting on the status of the department of Women and Gender Studies at Makerere, Kasente notes that:

\section{Notes}

1 Conference organised by KIT, the Royal Tropical Institute, Amsterdam, 14-16 May 2007.

2 KIT - revisiting gender training

3 Indeed these lamentations are not wholly negative because they alert society/governments to the need for change in policy and practice.

\section{References}

ActionAid Uganda (2006) Mapping the Women's Movement in Uganda: Present Realities and Future Directions, Kampala: ActionAid

Agarwal, B. (1997) 'Bargaining and Gender Relations Within and Beyond the Household', Feminist Economics 3.1: 1-51

Ahikire, J. (2007) 'Gender Training and the Politics of Mainstreaming in Post-Beijing Uganda', in $M$. Mukhopadhyay and F. Wong (eds), Revisiting Gender Training: The Making and Remaking of Gender Knowledge. A Global Sourcebook, Amsterdam: KIT

Ahikire J. (2005) 'On Women's Political Representation: A View on Potentials and
There is so much to do and there are so few people to do it that more time is spent on getting things done rather than on allowing space for reflection, strategic planning and monitoring. It is also very difficult to challenge the status quo. (Kasente 2002: 98)

With the popularity of gender mainstreaming whose logic is predicated on the fact that gender is a 'crosscutting issue', professed gender scholars are simply overwhelmed by the demands on their person. As I said earlier this is a direct result of some level of success - high demand for feminist scholars and more visibility of the gender equality question. But there is a vacuum created at another level - of building the discipline and more importantly, the feminist challenge. This is how I bring in the notion of managing success. In many cases, the requirement to 'do gender't is more lucrative than the much more tasking intellectualism. There is practically little incentive to do more thinking and theorisation. Managing success in this sense will require efforts to create a balance between roles - doing gender and thinking feminism.

4 Consultancies say to conduct gender training, gender audits and policy evaluation.

Limitations of Global Feminism in Contemporary Uganda', in C. Van Del Westhuizen (ed.), Gender Instruments in Africa: Critical Perspectives, Future Prospects, Midrand: Institute for Global Dialogue Ahikire, J. (1994) 'Bringing Women Back: A Search for Alternative Histographies. Quest: Philosophical Discussion', An International African Journal of Philosophy VIII.2: 2-19

de Beauvoir, S. (1949) The Second Sex, New York: Vintage Books

Goetz, A-M. (2003) 'Women's Political Effectiveness: A Conceptual Framework', in A-M. Goetz and S. Hassim (eds), No Shortcuts to Power: African Women in Politics and Policy Making, London: Zed Books 
Kasente, D. (2002) 'Institutionalising Gender Equality in African Universities: Women and Gender Studies at Makerere University', Feminist Africa 1, Cape Town: African Gender Institute

Kuesiga, J. (2003) 'The National Machinery in Uganda', in S. Rai (ed.), Mainstreaming Gender. Democratizing the State, Manchester: Manchester University Press

Lazreg, M. (2004) 'Beijing Plus Ten, or Feminism at Crossroads?', Feminist Africa 3, Cape Town: African Gender Institute

Mama, A. (1996) Women's Studies and Studies of Women in Africa During the 1990s, Dakar: Council for the
Development of Social Science Research in Africa (CODESRIA)

Mbilinyi, M. (1984) 'Research Priorities in Women's Studies in East Africa', Women's Studies International Forum 7.4: 289-300

Pereira, C. (2004) Bibliography on Sexuality, www.gusafrica.org/teaching/charmaine's\%20 essay.html (accessed 20 August 2008)

Stetson, D.M. and Mazur A.G. (1995) 'Introduction', in D.M. Stetson and A. Mazur (eds), Comparative State Feminism, London: Sage Publications 